\section{Pattern recognition: Are size and orientation additive factors?}

\section{DEREK BESNER \\ Reading University, Reading, England}

In a recent study, Sekuler and Nash (1972) investigated the effects of irrelevant size and orientation differences on the time taken to decide whether two forms were the same or not. Three findings are of interest: (1) The time to respond "same" increased monotonically as a function of the magnitude of the relative size difference between the two forms. (2) A $90^{\circ}$ difference in orientation between the forms slowed "same" decision time by approximately 70 msec. (3) When both orientation and size differences were present simultaneously, they had additive effects on reaction time.

Sekuler and Nash interpreted these results as evidence consistent with the hypothesis that size and orientation transformations are necessary to normalize the stimuli prior to comparison operations. In their view, size and orientation invariance is thus achieved by a time-consuming process of mental transformation, rather than on the basis of the extraction and comparison of size and rotation invariant features, as has been suggested by other pattern recognition theorists such as Corcoran (1971), Dodwell (1970), Gibson (1969), Milner (1974) and Sutherland (1973). Moreover, the finding that size and orientation effects were additive implies that these operations are sequentially organized such that one operation starts only after the other has finished (see Sternberg, 1969, for a discussion of additive stages logic).

The purpose of the present note is to point out that these conclusions were based only on the results of analyses performed on the reaction time data, the problems of which have been discussed at some length by Pachella (1974). In fact, an analysis of the error data' confirms that a significant interaction between size and orientation is present, $F(6,24)=$ $3.50, p<.02$. Clearly, then, the claim that size and orientation are additive factors is no longer tenable.

Finally, it should be noted that, in a recent experiment, Cavanagh (1977) has localized the effect of orientation on character classification time at a decision stage in the recognition process. If additive stages logic is accepted, then the presence of an interaction between size and orientation in the Sekuler and Nash study might be taken as indicating that size also has its effects after comparison rather than before, a locus that has been suggested previously by Besner and Coltheart $(1975,1976)$, and one that is inconsistent with the preprocessing explanation offered by Bundesen and Larsen (1975), Posner (1969), Posner and Mitchell (1967), and Sekuler and Nash (1972).

\section{REFERENCES}

Besner, D., \& Coltheart, M. Same-different judgements with words and nonwords: The differential effects of relative size. Memory \& Cognition, 1975, 3, 673-677.

Besner, D. \& Coltheart, M. Mental size scaling examined. Memon' \& Cognition, 1976. 4. 525-531.

BUNDESEN, C.. \& LARSEN, A. Visual transformation of size. Journal of Experimental Psychology: Human Perception and Performance, 1975, 1, 214-220.

Cavanagh, P. Locus of rotation effects in recognition. Bulletin of the Psychonomic Society. 1977, 10. 101-104.

CorCoran. D. W. J. Pattern recognition. Harmondsworth, England: Penguin Books, 1971.

DODWELl. P. C. Visual pattern recognition. New York: Holt Rinehart and Winston. 1970.

Ginson, E. J. Principles of perceptual learning and development. New York: Appleton-Century-Crofts, 1969.

Milner. P. M. A model for visual shape recognition. Psychological Review, 1974. 81, 521-535.

PACHella. R. G. The interpretation of reaction time in information processing research. In B. Kantowitz (Ed.), Human injormation processing: Tutorials in performance and cognition. Hillsdale, N.J: Erlbaum, 1974.

PosNer, M. 1. Abstraction and the process of recognition. In G. Bower (Ed.), Advances in learning. New York: Academic Press. 1969.

Posner, M. I.. \& Mitchell, R. F. Chronometric analysis of classitication. Psychological Review. 1967, 74, 392-409.

Sekuler, R., \& NAsh, D. Speed of size scaling in human vision. Psychonomic Science, 1972, 27, 93-94.

Sutherland. N. S. Object recognition. In C. Carterette \& P. Friedman (Eds.), Handbook of perception. New York Academic Press, 1973.

Sternberg. S. The discovery of processing stages: Extensions of Donder's method. In W. G. Koster (Ed.), Attention and performance II. Acta Psychologica, 1969, 30, 276-315.

\section{NOTE}

1. I thank Robert Sekuler for providing the error data.

(Received for publication September 26, 1977.) 